\title{
Effects of Scale and the Biophysical Environment on Sense of Place in Northeastern Wisconsin's Bioregions
}

\author{
Francis Eanes ${ }^{1}$ \\ Environmental Studies Program, Bates College, Lewiston, \\ ME, United States \\ Patrick Robinson \\ Department of Agriculture and Natural Resources, \\ University of Wisconsin-Madison Cooperative Extension, WI, United States \\ Janet Silbernagel \\ Nelson Institute for Environmental Studies, \\ University of Wisconsin-Madison, WI, United States
}

\section{Abstract}

Understanding individuals' and groups' sense of place can provide insights into how people interact with and treat both natural and built environments, but empirical-place scholarship has paid relatively little attention to several key dynamics, including the existence and implications of broad-scale sense of place, and the biophysical (and bioregional) dimensions of sense of place. Accordingly, this empirical, phenomenological study investigates the scale at which sense of place develops and operates among a subset of residents engaged in watershed conservation activities in northeastern Wisconsin's mixed-amenity coastal communities. In total, 22 semi-structured interviews were conducted with individuals who were vocationally or avocationally involved in water-quality improvement and/or broad-scale conservation activities in northeast Wisconsin. Results indicate that biophysical landscape characteristics, particularly water, enable the sorts of meaningful social and sensory experiences that ultimately develop into a sense of place at varying geographic scales.

Keywords: sense of place, scale, landscape characteristics, bioregionalism

1 Corresponding author: feanes@bates.edu. 


\section{Introduction}

The last 15 years have seen an exponential growth in the scholarship on peopleplace relationships, with disciplinary contributions coming from environmental psychology, human ecology, human geography, leisure studies, anthropology, urban studies, and rural, community, and environmental sociology—just to name a few (Lewicka, 2011). Though the motivations for conducting and applying place scholarship are as diverse as the field's disciplinary roots, understanding people's sense of place-that is, the "affective bond[s] or link[s] between people and specific places" (Hidalgo \& Hernandez, 2001, p. 274)—can provide insights into how people interact with and treat both natural and built environments (Gosling \& Williams, 2010). The findings of sense-of-place research can, for example, inform understandings of pro-environmental behavior (Scannell \& Gifford, 2010a; Vaske $\&$ Kobrin, 2001), place-protective action (Lukacs \& Ardoin, 2014), management of regional amenities (Carrus et al., 2005), participatory landscape planning (Manzo $\&$ Perkins, 2006), and environmental education initiatives (Kudryavtsev et al., 2012). In short, place matters (Gifford, 2014).

Despite these invaluable contributions, empirical place scholarship has paid relatively little attention to several key dynamics, including the existence and implications of broad-scale sense of place, and how social sense of place is affected and influenced by biophysical landscapes (Lewicka, 2011). Ardoin (2014), for example, notes that despite the broad-scale nature of ecological issues such as water quality impairment, and habitat loss, a surprising dearth of scholarship addresses how a similarly broad-scale sense of place might affect environmental management and behavior at congruent scales. Similarly, despite the work of Stedman (2003) and others, the extent and means by which the biophysical environment influences people's overall sense of place are poorly understood. To begin to address these gaps, this empirical, phenomenological study examines how sense of place develops and operates among a subset of residents engaged in watershed conservation activities in three northeastern Wisconsin (United States [US]) bioregions (i.e., broad-scale landscape units containing distinct assemblages of flora, fauna, topography, and climatic features, and the spectrum of their associated sociocultural perceptions). By qualitatively exploring how sense of place operates across a variety of scales, and how the biophysical environment and bioregional patterns influence sense of place, we advance under-explored elements of sense-of-place theory, and offer guidance and hypotheses for future quantitative sense of place investigations. 


\section{Background on place dynamics}

\section{Definitions of place}

Place, according to Cresswell (2004), is a rather paradoxical concept both within and outside geographic disciplines, largely due to its ubiquity, deceiving simplicity (everybody knows what a place is, right?), and enigmatic qualities. "Place is everywhere. This is what makes it different from other terms in geography, like 'territory,' which announces itself as a specialized term, or 'landscape,' which is not a word which permeates through our everyday encounters" (Cresswell, 2004, p. 2). Tuan (1977) defines place in relation to space, asserting that if we imagine "space as that which allows movement, then place is pause; each pause in movement makes it possible for location to be transformed into place;" places, accordingly, are the sorts of things to which we develop affective bonds, and which form a significant part of our identity (p. 6). Massey (1994) views place as "articulated moments in networks of social relations and understandings" that are unavoidably contested in their delineation, and plural in how they are constructed and experienced (p. 154). While we embrace these constructivist and interactionist definitions, our work also recognizes the physicality and materiality of place-that is, the biotic and abiotic elements of whole ecosystems that both affect and are affected by the constructed human experience of place (cf. Dunlap \& Catton, 1979). Accordingly, our approach to place is best grounded in the perspective of critical realism articulated by some environmental sociologists (e.g., Bell \& Ashwood, 2015; Carolan, 2005). Places, we argue, are layered social-ecological systems; they cannot be solely reduced to either their biophysical dimensions or their varied and socially constructed meanings.

\section{Sense of place}

Given the disciplinary diversity of scholarship on the topic, sense of place can be conceptually confusing and has generated what some have called a "messy" literature (e.g., Beckley, 2003; Hidalgo \& Hernandez, 2001). Both sense of place and place attachment have been used as overarching terms to describe the cognitive, affective, or attitudinal relationships between people and places (Patterson \& Williams, 2005). While the former term is generally construed as the most conceptually inclusive due to its consideration of both positive and negative associations with place, the latter is presently the most commonly used in the literature, and generally preferred by environmental psychologists (Trentelman, 2009). Place attachment has been operationalized as an affective bond comprising place dependence-that is, the instrumental indispensableness of a place (e.g., Kyle et al., 2004; Stokols \& Shumaker, 1981) — as well as place identity (i.e., the notion that a place is part of how a person sees themself or wants to be seen by others) (Proshansky, 1978). Sense of place, meanwhile, has been variously operationalized as the sum of place dependence, place identity, and place attachment (e.g., Jorgensen \& Stedman, 2001), or as the sum of 
place attachment and place meaning, with place meaning typically comprising place dependence and place identity (Williams, 2014). We used this final conceptualization of sense of place to frame our interview questions and initial data coding scheme.

\section{Biophysical dimension}

Responding to the tendency for social and psychological dynamics to dominate place research, Stedman's (2003) article represents a significant turn in the literature, particularly for researchers interested in natural resource issues. Through his quantitative analysis of place meaning and attachment for lake homeowners in northern Wisconsin, he argues that the physical environment (whether built or natural) constitutes a potentially significant, if overlooked, dimension of sense of place. He observes that landscape characteristics such as land use, land cover, and population density collectively produce meanings (e.g., solitude, beauty, wilderness) to which people develop affective bonds of attachment. Human geographers (e.g., Relph, 1976, 1981) and environmental historians working within the tradition of cultural landscapes (e.g., Least Heat-Moon, 1991; Schama, 1995) have also made theoretical contributions to the ways in which landscapes and regions influence human culture. Stedman's call for increased attention to the physical environment has gained some traction (e.g., Ardoin, 2014; Beckley, 2003; Scannell and Gifford, 2010a) and has been included in two prominent organizing frameworks for holistically describing sense of place (Ardoin et al., 2012; Scannell \& Gifford, 2010b). However, the characteristics of physical environments and the means by which those characteristics influence affective bonds of attachment remain relatively under-explored, and significant questions regarding human-environment relationships remain (Lewicka, 2011).

\section{Scale}

Like biophysical landscape dynamics, several place scholars have noted that the spatial scale of the places to which people form bonds remains largely understudied (Hidalgo \& Hernandez, 2001). Lewicka (2010) contends that most studies do not explicitly examine the relationship between sense of place and scale, and tend to use either a single scale (e.g., home, neighborhood, city) or a vaguely defined scale (e.g., "this place") when measuring sense of place. Among these single-scale studies, moreover, the most common scale of measurement is the neighborhood or community, with a much smaller share of studies focusing on the home, and only a tiny number examining scales of attachment broader than a city (Lewicka, 2010). Among the handful of comparative, multi-scalar studies, conflicting conclusions have been drawn, producing no definitive results. Finally, few studies have investigated sense of place at scales broader than the city, and even fewer have assessed the impact of these broader-scale attachments on pro-environmental behavior (Lewicka, 2011). In the rare instance when both broad-scale sense of place and pro-environmental behaviors are measured (e.g., Forsyth et al., 2015), the 
findings are complicated by a general lack of congruence between the scale of an individual's sense of place and the pro-environmental behaviors that are measured (see Ardoin [2014] and Mullendore et al. [2015] for notable exceptions). Given the broad-scale nature of contemporary ecological challenges and the attractiveness of similarly scaled conservation strategies, we argue that this lack of study represents a significant missed opportunity.

\section{Bioregions and bioregionalism}

Bioregions have been proposed as broad-scale spatial terrestrial units that can be useful for understanding socioecological landscape patterns (Rutherford et al., 2006). Bioregions are conceptually similar to ecoregions, in that both are "areas of distinct assemblages of plants and animals with dynamic but clear topographic and climatic boundaries" (Banting, 2012, p. 788). Further, both are hierarchically located on the scalar spectrum between the vast, broad-scale biome (continental) unit, and smaller ecological units such as ecosystems, communities, or populations (Selman, 2006). However, what makes bioregions conceptually distinct from ecoregions - and of particular interest to this study - is the former's inclusion of social and cultural dynamics. Thayer (2003), for example, insists that humans and all the trappings that come with human culture (e.g., art, cuisine, design, economies) ought to be considered essential parts of any given bioregion, along with bioregions' ecological, geological, and climatic characteristics.

Some of the more radical promoters of bioregionalism (e.g., Sale, 1985) have been deservedly criticized for being too parochial and reactionary (Massey, 1994), essentializing (Painter, 2008), environmentally deterministic (Berthold-Bond, 2000), and too easily co-opted by right-wing, exclusionary ecological and social movements (Olsen, 2000). Despite these criticisms, Thayer (2003) and Selman (2006) argue that bioregions constitute an effective spatial unit for conceptualizing and addressing environmental challenges like water quality, which tend to follow landscape and environmental counters much more readily than political designations. In this article, accordingly, we use bioregions more as conceptual frameworks and spatial units through which to analyze our data, rather than as a prescriptive norm or a political ecosophy.

\section{Study area and research questions}

Our study area's three bioregions are situated in the western portion of the Great Lakes, the largest freshwater system on earth. Northeast Wisconsin is largely composed of three adjacent but distinct bioregions, with Lake Michigan's Green Bay (GB) serving as the area's central and most dominant geographic feature (see Figure 1). Traveling 40-50 miles northwest of the bay, one enters the southernmost reaches of the Northwoods bioregion, a mosaic of Pine Barrens, glacial moraines and drumlins, and northern hardwood forests. Referred to by many upper Midwesterners as "up north," this bioregion is pocked with thousands of 
small lakes, a low population density, and a relatively high proportion of second homes, often adjacent to lakes (Stedman, 2003). In stark contrast, most of GB's eastern shore comprises the Door Peninsula (DP) bioregion, a karst landscape formed by the erosion of the underlying Niagara escarpment. With its shallow soils and a regionally unique climate (moderated by its immediate adjacency to both GB and Lake Michigan), the DP enables forms of agriculture less common elsewhere in the state, particularly stone fruit production. The DP's scenic lake views and orchard access, meanwhile, attract a high number of tourists from southern Wisconsin's and northern Illinois's urban areas. Although they are all subjected to many of the same macro-scale drivers of change in the western Great Lakes basin, these three bioregions' assemblages of flora, fauna, landforms, and land-use patterns make them somewhat distinct from one another, both in terms of their current ecological challenges and their sociocultural associations.

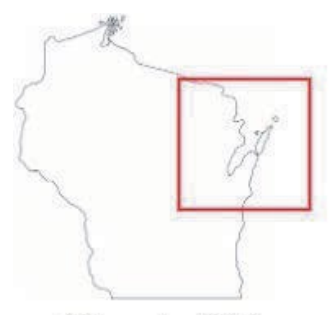

Wisconsin, USA

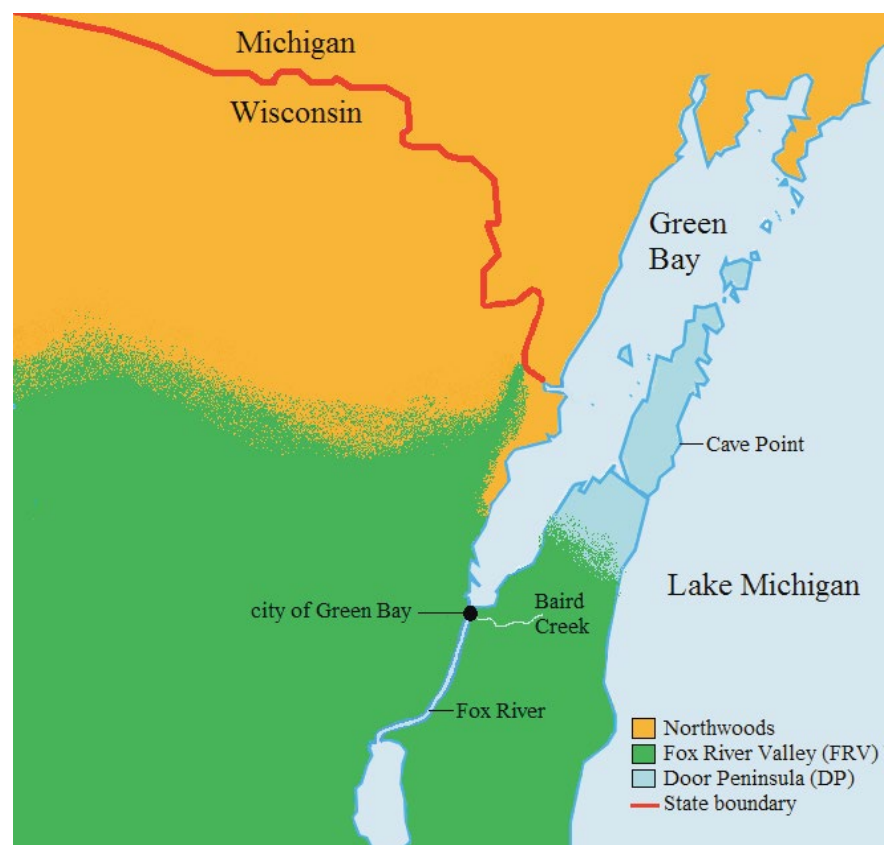

Figure 1. Study area: northeast Wisconsin and its bioregions, including the Northwoods, Door Peninsula, and Fox River Valley

Source: Map adapted from US Environmental Protection Agency (2013).

Finally, most of this study's participants live in the Fox River Valley (FRV) bioregion. Situated at the southern end of GB and between the Northwoods and the DP, the FRV is a series of lacustrine till and clay plains. Estuaries and wetlands on GB's west shore-which are largely state-owned and protected, and among the Wisconsin Department of Natural Resource's "Legacy Places" - create unique habitats, vital to the wildlife they support, and are some of the most productive wetlands in the upper Midwest. Despite these rich amenities, the FRV has a troubled aquatic 
legacy, with alarmingly high rates of heavy metals, sediment, agricultural pollutants (e.g., phosphorus and nitrogen), and aquatic invasive species throughout the Fox River and southern GB (Vander Zanden \& Olden, 2008). Combined with significant wetland loss, fish declines, and increasing harmful algal blooms and flood events, the FRV remains a federally listed Area of Concern (Brazner, 1997).

In sum, this article considers northeastern Wisconsin and its constituent bioregions as a mixed-amenity place. Given this context and the foregoing discussion of our conceptual orientations and assumptions, the following questions guided our research:

1. What sorts of biophysical characteristics, meanings, and/or experiences affect sense of place?

2. How does scale affect social and biophysical sense of place, particularly with regard to people's reported pro-environmental behaviors?

\section{Methods}

Given our goal of exploring in depth the complex relationships among sense of place, scale, biophysical landscapes, and environmental behavior, we opted for an empirical, phenomenological approach (Patterson \& Williams, 2002). Between May 2014 and May 2015, we conducted 22 semi-structured, in-depth interviews. Since we were in part interested in understanding how a bioregional sense of place may operate for people engaged in broad-scale conservation action, we used a combination of purposive and snowball sampling (Miles \& Huberman, 1994) to identify individuals who met two criteria:

1. Their principle residence was in the FRV bioregion.

2. They were vocationally or avocationally involved in water quality improvement and/or broad-scale conservation activities in one or more of our study area's three bioregions.

These criteria were chosen because of the broad-scale nature of water quality challenges and their associated solutions in the Great Lakes basin. Interview participants were purposefully selected to maximize diversity in terms of age and length of residence in the FRV bioregion. Interviews were conducted in participants' place of residence or place of work, and lasted between 40 minutes and two hours (mean $=70$ minutes). Questions were approved by our institutional review board, and adapted in part from Ardoin's (2014) comparative sense-of-place and scale-ofplace survey questions, with others specifically designed to elicit associations with and connections to various bioregional dynamics. Others targeted respondents' meaningful place and place-based experiences (e.g., recreation activities), as well as their motivations for participating in water quality improvement and other broadscale landscape conservation activities. Probing, follow-up questions were asked throughout to provide clarification and depth of insight. 
All interviews were audio-recorded and transcribed verbatim. We used the qualitative data analysis package Atlas.ti to sort and code data. Following Timmermans and Tavory's (2012) modified grounded theory approach, which prioritizes abductive rather than purely inductive data analysis and theory construction, we first utilized an a priori coding scheme to provide initial structure and analytical categories (see Table 1). This scheme, based on literature described by Williams (2014), treated sense of place as an overarching construct composed of the dimensions place meaning and place attachment. Place meaning included the sub-dimensions place identity and place dependence. Next, per our research questions, we analyzed these dimensions through categories of biophysical characteristics and meanings mix-amenities, and scale. In addition, given our interest in the intersection between bioregionalism and sense of place, we coded all data relevant to the categories of bioregional awareness, perceptions, and boundaries. After generating an initial list of codes, we returned to our codes and data, asking subsequent analytical questions about how our initial codes related to one another, and to our initial research questions. Our findings were based on the codes and subcodes that resulted from this latter analysis.

\section{Results}

\section{Participant demographics}

Interview participants included seven females and 15 males, who ranged in age from 18-84 $($ mean $=45)$ and in length of residence in the FRV from 2-55 years $($ mean $=23)$. Though two of our respondents presently live in the southern DP, they have both previously lived and currently work in the FRV. All participants are involved either vocationally or avocationally in water quality improvement activities and other conservation initiatives throughout northeastern Wisconsin. Categorical examples of participants' vocations included water-related research positions affiliated with the University of Wisconsin-Green Bay; coordinators of watershed monitoring, education, and outreach programs; and environmental science high school teachers. Examples of participants' avocational activities included serving on regional waterand conservation-related nongovernment organization boards; volunteering time to support watershed cleanup projects; lobbying elected officials on water-related bills; and voluntary leadership in watershed education and outreach. All participants expressed a deep connection to northeast Wisconsin and its constituent bioregions, with particular affection reserved for the perceived uniqueness of the area's immense freshwater water resources. In the following sections we analyze our respondents' sense of place through the lenses of biophysical place dynamics, mixed-amenity places, and the scales (particularly bioregional) at which sense of place operates and links to broadscale environmental behavior. 
Effects of Scale and the Biophysical Environment on Sense of Place in Northeastern Wisconsin's Bioregions

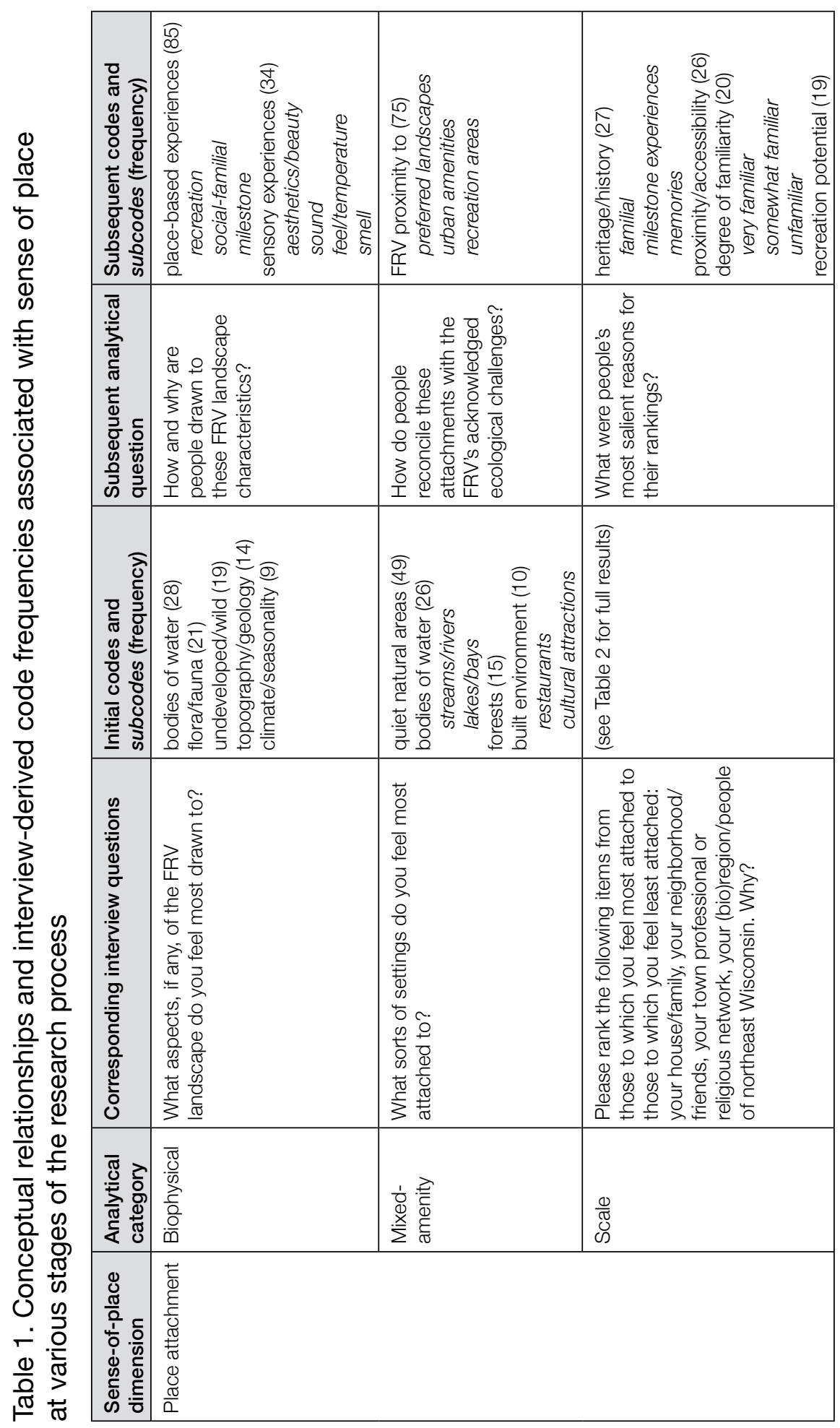




\begin{tabular}{|c|c|c|c|}
\hline 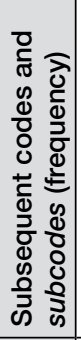 & 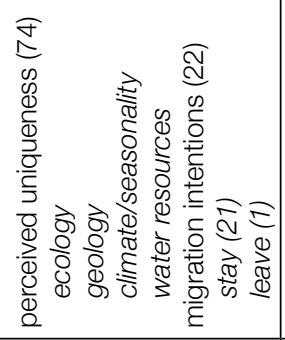 & 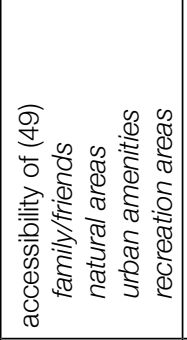 & 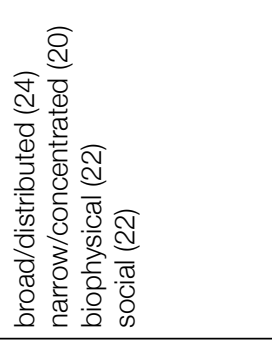 \\
\hline 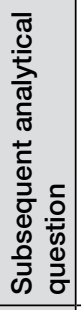 & 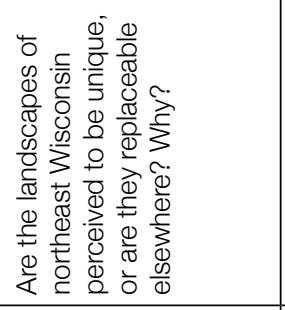 & 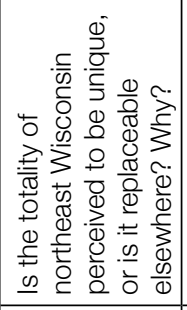 & 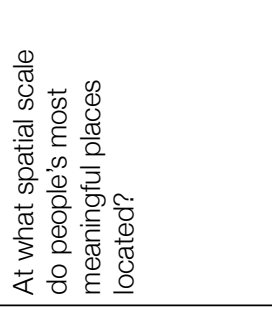 \\
\hline 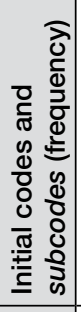 & 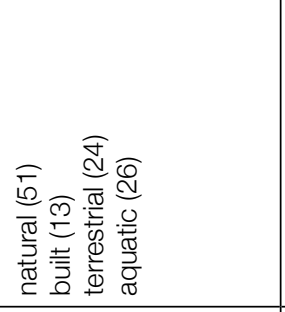 & 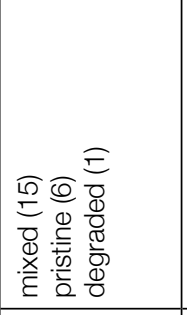 & 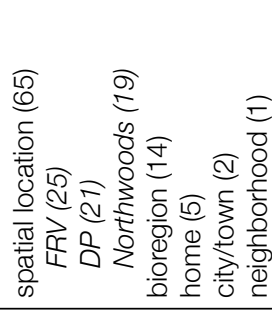 \\
\hline 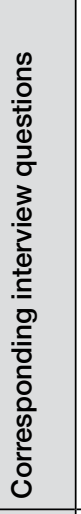 & 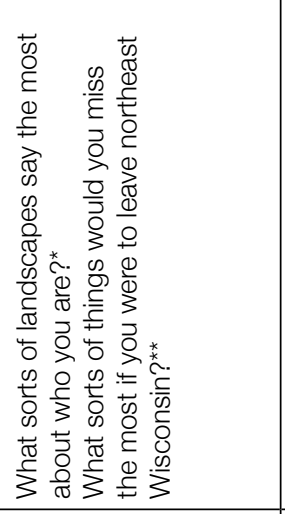 & 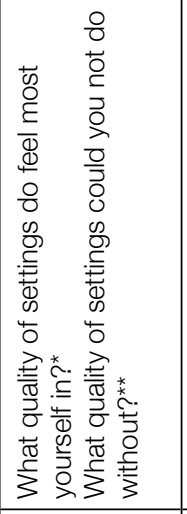 & 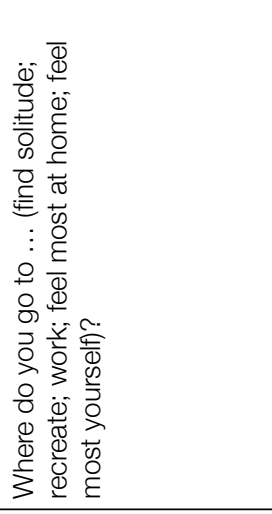 \\
\hline 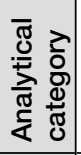 & $\begin{array}{l}\overline{\frac{0}{0}} \\
\frac{0}{0} \\
2 \\
\frac{0}{0} \\
\frac{0}{0} \\
\end{array}$ & 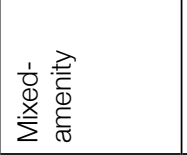 & 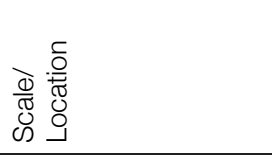 \\
\hline 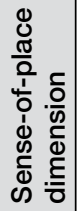 & 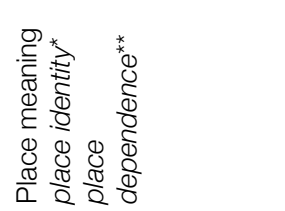 & & \\
\hline
\end{tabular}




\section{Biophysical place dynamics}

Though a majority of participants' social ties were the most salient component of their sense of place, their connection to northeastern Wisconsin's biophysical landscapes emerged as a strong, synergistic component—one that influenced the sorts of socially constructed meanings and social experiences that shaped their respective place attachments, dependences, and identities. This phenomenon most frequently grounded in a deep affinity for the particular kinds of topography, climate, and landscape features (particularly water bodies) that typify the region.

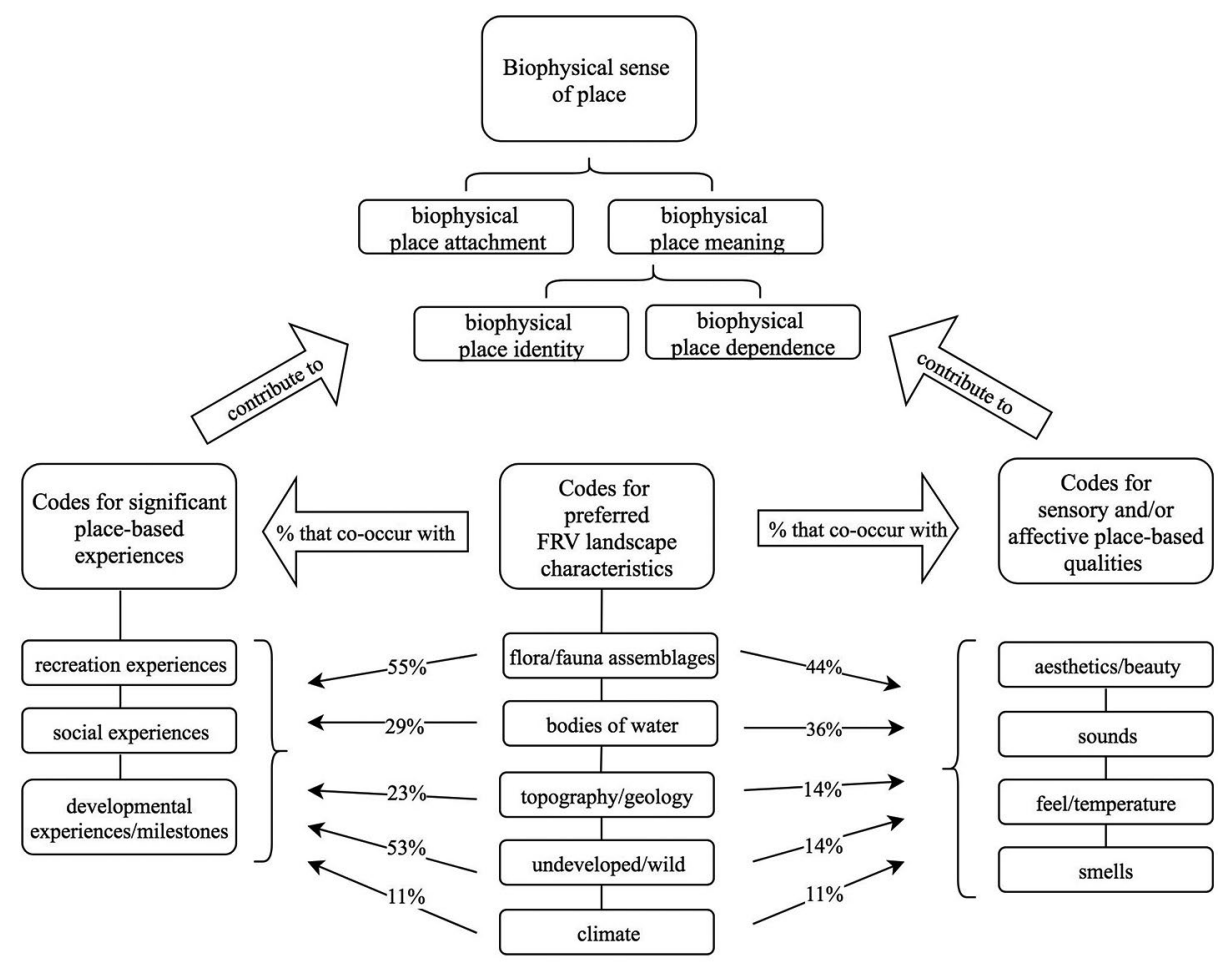

Figure 2. Conceptual model depicting how sense of place (top) is connected to interview participants' preferred landscape characteristics (bottom-center column) through significant place-based experiences (bottom-left column) and sensory/affective place-based qualities (right-bottom column)

Note. Code co-occurrence refers to the percentage of all occurrences of a landscape characteristic code (e.g., flora/fauna assemblages) that are linked to the same sample of interview text as one of the codes in either the left or right columns (e.g., recreation experiences).

Respondents overwhelmingly identified a common set of biophysical landscape characteristics that they preferred, and which in their view, made northeastern Wisconsin qualitatively distinct from the rest of the state and upper Midwest. 
After their friends and family, participants most frequently said that, were they to move away, these biophysical characteristics would be the hardest to find in a new place. Below we discuss these landscape characteristics-including water, climate, and topography/terrain — and how they strengthen sense of place through sensory and experiential pathways (see Figure 2).

In a landscape dominated by the largest freshwater system on earth, it is perhaps unsurprising that residents of that landscape would express a strong affinity for water. According to respondents, water connects all other landscape elements, a sort of common denominator that provides coherence for northeastern Wisconsin's bioregions. For some, the attraction to water has an almost incommensurable aspect to it, as articulated by a 34-year-old female, who talked about the irreplaceability of the Great Lakes, and the uniqueness of GB and Lake Michigan in particular:

Researcher: What I'm getting at is, what about this region can't be replaced?

Participant: The water.

Researcher: Which water?

Participant: The big water. Being able to drive five minutes and look out over the water and you can't see the horizon.

Researcher: Would you feel that way living in coastal California?

Participant: Right. I think the ocean's different. I've seen the ocean, and it's different. It's a different color. It has a different smell.

Researcher: If you would take your family to Saginaw Bay or somewhere like Lake Erie.

Participant: Lake Erie is gross.

Researcher: So even within the Great Lakes it depends where you go?

Participant: Yes, it does. I have family in upstate New York and we visited Lake Erie and Lake Ontario. You can't walk on the beach; it's dirty, smelly. The people are different. It's some of those things that you can't quite put your finger on ... it's just different.

For this participant, large bodies of water are clearly important. Yet not just any large body of water will suffice; there are demonstrable, qualitative differences between living and recreating on an ocean-or even the shallower, more algae-prone eastern Great Lakes-compared to GB and Lake Michigan. This water-mediated place dependence- that is, the sense that this lake(s) and not just any large water body will do-emerged again and again throughout the interviews, and underscores the importance of the biophysical dimension of sense of place. In addition to water, many respondents identified northeastern Wisconsin's climate as another biophysical 
feature to which they have become attached, echoing the findings of Knez (2005). Participants talked about the senses of anticipation and relief that accompany the variety and predictability of seasonal change. Though some certainly expressed displeasure at the cold winters, many others talked at length about various winter activities-ice skating, cross skiing, ice fishing, snowmobiling - that are possible, and which make that season not only bearable, but even enjoyable.

Like water and climate, participants expressed a strong attraction for the area's varied terrain and the distinct assemblages of flora and fauna that it supports. Respondents were particularly attuned to northeastern Wisconsin's glacial past, and fond of the landscape patterns carved by glacial retreat. This affection for the landscape is captured well by a 71-year-old longtime resident, who remarked:

When they talk about things that people are attracted to seeing beauty-wise, we don't have mountains or oceans here, but you've got interesting terrain. It's not flat. You have beautiful ups and downs, and I think that creates more interest. We've got interesting topography, beautiful moving water. There are places where you can stand beside the stream and listen to the sound of the water. Clear water running over smooth rock has a lot of aesthetic appeal. Then, there are huge trees.

Responding to the implicit notion that oceans and mountains are presumed to have more innate beauty or sublimity, this individual makes a case that the upper Midwest's postglacial landscapes offer a similarly deep appeal. Wholly unprompted and almost defensively, many respondents made comments that favorably compared the scenic quality of this so-called "flyover country" to the US's more typically celebrated mountains and sea coasts.

In addition to landscape preferences, the quote above illuminates an important means by which respondents expressed their attachment to specific landscapes-namely, through sensory experiences. While previous research on biophysical attachments to place have emphasized an abstracted, meaning-mediated connection (e.g., Stedman, 2003), landscapes' sensory qualities (e.g., the sound and sight of moving water, as in the quote above) emerged as an important, if not equally significant, factor that participants used to explain their biophysical sense of place. Like the woman quoted earlier who distinguished between GB/Lake Michigan and other bodies of water on account of their smell, another respondent described the sounds, tastes, and warmth associated with another northeastern Wisconsin place. Speaking of Cave Point, a shoreline segment of 20-foot dolomite cliffs overlooking Lake Michigan in the DP, this individual recalled:

My wife and I, at least once a winter, go to Cave Point in January or February. There's sea ducks there, species you usually only see in the Arctic Ocean, golden eyes and red-breasted mergansers and old squaw and skoaters and things like that. We're bird watchers, so we go up there and bird-watch and go to the warming shelter 
at Whitefish Dunes and start a big fire and have a couple of bottles of wine and a picnic lunch and read poetry to each other as we listen to the waves smash up on the shore. It's just great, something we'll talk about for a month afterwards.

For this individual, the bond with Cave Point is doubtlessly influenced by the perceived ecological uniqueness of the area (e.g., the rare presence of sea ducks) and the place-enabled, personally meaningful experience of bird-watching with his wife. And yet what also makes this place special and particularly memorable is the feeling of warmth from the fire, and the sound of poetry and waves crashing on the shore, the taste of the wine and picnic lunch. These synergistic senses are uniquely associated with that place, and in part are what provoke the telling and retelling of that experience "for months afterwards."

\section{Scale of place}

We asked participants to talk about their relative sense of place in their house, their neighborhood, their town or city, and northeast Wisconsin's regional landscapes. Almost half said they felt most strongly connected to the region's landscapes, followed by their sense of connectedness to their house, neighborhood, and town/ city, respectively. All but three ranked their regional connectedness first or second. While it at first seemed puzzling why participants could possess similarly strong senses of place at both narrow and broad scales, it turns out that these valences of attachment, which Ardoin (2014) refers to as people's scale of place, are hardly uniform and operate somewhat distinctively. Narrower social scales of place (e.g., house, neighborhood, town) almost always comported with the valence of participants' strongest social networks (see Figure 3). For example, participants who lived with and felt most connected to their immediate family (as opposed to broader-scale networks like friends, coworkers, religious affiliates, or other members of their ethnic/racial identity) most commonly associated this familial bond with their house (see Table 2). One 61-year-old retiree, for example, explained it this way:

[My wife] and I are big yard people. We live outside during the summer. We eat every meal out there, we garden together, we plant flowers together-that's a big thing. We have our coffee and walk in our yard all summer long. I think my home is now, as a retired person, where I spend the bulk of my time and time with my wife. I don't know if everybody would feel that way, but for me, my wife is my best friend, the most important thing to me in life. Where I spend time with her is where is going to be most important to me.

The house enables the most regular contact and activity with this man's wife; it is where he spends the most time, and where (as he said later in the interview) he sees his two daughters when they come to visit. Respondents often blended these house/ home and familial/household bonds, and described their combination as something that leads to familiarity, comfortability, and a deep sense of place. 
Table 2. Scale of place

\begin{tabular}{|c|c|c|}
\hline & Social & Biophysical \\
\hline $\begin{array}{l}\text { Broad } \\
\text { Scale }\end{array}$ & $\begin{array}{l}\text { Sense of place strongest when: } \\
\text { - } \text { respondents described deep bonds } \\
\text { with a spatially diffuse } \\
\text { - } \text { social network } \\
\text { Number }(n) \text { of respondents who feel } \\
\text { most socially connected to: } \\
\text { - professional organizations }(n=2) \\
\text { - dispersed extended or immediate } \\
\text { family }(n=3) \\
\text { Most salient reasons for attachment: } \\
\text { - regional travel for work } \\
\text { - regional family history/roots }\end{array}$ & $\begin{array}{l}\text { Sense of place strongest when: } \\
\text { - } \text { respondents described strong familiarity with } \\
\text { - } \text { and affinity } \\
\text { Number regional landscapes } \\
\text { biophysically connected to: } \\
\text { - landscapes of northeastern Wisconsin }(n=9) \\
\text { - Great Lakes system }(n=5) \\
\text { - bay of GB (n=5) } \\
\text { Most salient reasons for attachment: } \\
\text { - proximity to recreational opportunities } \\
\text { - climate/seasonality } \\
\text { - topography/land cover } \\
\text { - bodies of water }\end{array}$ \\
\hline $\begin{array}{l}\text { Narrow } \\
\text { Scale }\end{array}$ & $\begin{array}{l}\text { Sense of place strongest when: } \\
\text { - } \text { respondents described deep bonds } \\
\text { with a spatially } \\
\text { - } \text { concentrated social network } \\
\text { Number (n) of respondents who feel } \\
\text { most socially connected to: } \\
\text { - immediate family living at home } \\
\text { ( }(n=15) \\
\text { - close friends who live in town }(n=2) \\
\text { Most salient reasons for attachment: } \\
\text { - never lived elsewhere } \\
\text { - lacks meaningful professional } \\
\text { - } \text { immennections } \\
\end{array}$ & $\begin{array}{l}\text { Sense of place strongest when: } \\
\text { - respondents described strong and affinity } \\
\text { for more } \\
\text { - intimate, nearby places } \\
\text { Number (n) of respondents who feel most } \\
\text { biophysically connected to: } \\
\text { - house (n=3) } \\
\text { Most salient reasons for attachment: } \\
\text { - love of yard } \\
\text { - preference for indoor activities } \\
\text { - lack of mobility }\end{array}$ \\
\hline
\end{tabular}

Note. Participants reported feeling strong biophysical and social attachments, which varied across scales depending on the relationship between (a) the relative importance of their various components of their social networks and biophysical attachments, and (b) the scale corresponding to those respective social and biophysical components.

\section{Bioregional patterns}

As the intensity of their social sense of place dissipated across broader social scales, however, these very same participants increasingly referred to biophysical and landscape characteristics to explain their strong regional attachments, identities, and dependences. Respondents consistently talked about deep bonds with a variety of specific places throughout the FRV, DP, and Northwoods-a compilation of meaningful spots that one participant described as his "distributed sense of place." As described in the foregoing sections, those attachments are, by and large, the often incommensurable sum of participants' (1) affinity for those bioregions' climate, topography, and terrestrial aquatic landscapes; and (2) the proximate assortment of recreational activities, sensory experiences, associated place meanings (e.g., solitude), and memories made possible by those bioregions' biophysical characteristics. The same retiree quoted above, for example, mentioned what he would miss most if he were to move away from northeast Wisconsin: 
Well, one of the things I would miss is outdoor recreation. There are other places in the country that might be slightly better, but there's a lot of places that would be a lot worse. If I were to go back to my hometown [in central Iowa], you don't have forests. You have the Iowa River, which is pretty. There's no whitewater on it, and you don't have beautiful lakes. I think that is one of the advantages of this part of the country. You can take part in big cities and their cultural activities that they offer, but then also it's not that long a drive and you can be out in the countryside in the rural areas and areas that have extensive undeveloped habitat, so it's all pretty easily accessible.

For this individual, proximity to recreational areas and landscape preferences (i.e., forests and lakes) are a significant regional magnet. Combined with readily available cultural and urban amenities, he identifies a preferential regional distinctiveness and advantageousness that was continually expressed by both shortand long-term residents in our sample. While the term "bioregion" was never explicitly used, the language participants used to describe this perceived regional uniqueness — and how this uniqueness influenced their sense of place-demonstrates a keen awareness of bioregional characteristics, both within and beyond northeastern Wisconsin. A 48-year-old geologist, for example, commented:

I like the seasons and the ecology of the area, the kinds of plants and animals. That would be certainly different in many other places that I would move. There's also something about the general culture of the place. I was really surprised after living outside of Wisconsin how different things are. There's something unique about this area and it's not solely the fact that they're moderated by the Great Lakes because you don't get them in other Great Lakes. There's something different about this area. It's got a whole complex array of geological things. It's got a whole bunch of boundaries with the prairie deciduous ecotone, I think they call it. You get the boundary between the conifer forest in the north and deciduous forest down here [in the FRV], and you get a whole bunch of other weird stuff with sand. It's a neat area.

Ecotonal variety (i.e., climatic and flora/fauna variability) among the FRV, DP, and Northwoods bioregions is quite apparent and attractive to him. Due to his vocation, it is perhaps unsurprising that he is able to readily identify and talk about these biotic and abiotic differences. But like so many others, he also adds that the "general culture of the place" not only feels different than other places he has lived (which included Kansas, Michigan, and Maryland), but is itself appealing. Like every other respondent, he expressed certainty that northeastern Wisconsin is composed of three qualitatively distinguishable bioregions, and should not be considered a singular, homogeneous entity. While he, like others, confidently articulated the existence and nature of certain kinds of bioregional boundaries, he struggled to put into words other, more nuanced and perceptual qualities. Geographic boundaries based on readily detectable landscape and land-use patterns emerged as the clearest and most easily definable, and were most closely associated in participants' minds with varying population densities and a sociocultural "feel." The Northwoods, 
for example, were most frequently associated with relaxation, hunting, fishing, or just "getting away from it all." With a very low year-round population and clusters of vacation-oriented lake homes, the Northwoods are:

a whole different type of land. You get north of say Highway 64 and you no longer have agriculture; it's forest and lakes. When I think of up north, that's what I think of, forests and lakes. You don't have corn fields, bean fields, etc. You have a few scattered dairy farms here and there.

While individuals differed on the precise geographic location of this and other boundaries, the existence of perceived differences was largely agreed upon. Further, bioregional patterns and distinctions-whether ecological or sociocultural, or incommensurably felt or concretely observable-were expressed as admittedly fuzzy boundaries, and did not preclude participants from identifying larger, commonly felt threats (e.g., climate change) and opportunities within northeastern Wisconsin or, more generally, the Great Lakes basin (see Table 3). However, when talking about what frames and sustains the vocational and avocational work they do on behalf of environmental protection and water quality issues, they preferred geographically smaller units. One 51-year-old woman, for example, said:

I still feel very connected to the [FRV] region. Very much so. I really have found, as I've gotten older, I have a sense of place. Especially after coming to University of Wisconsin-Green Bay and learning about environmental science. It's really made me see how the world works in general, but how important it is to have that sense of place to, I guess, solve the problems of the world. You can't solve any big problems, but you can at least solve something in your local area in some way.

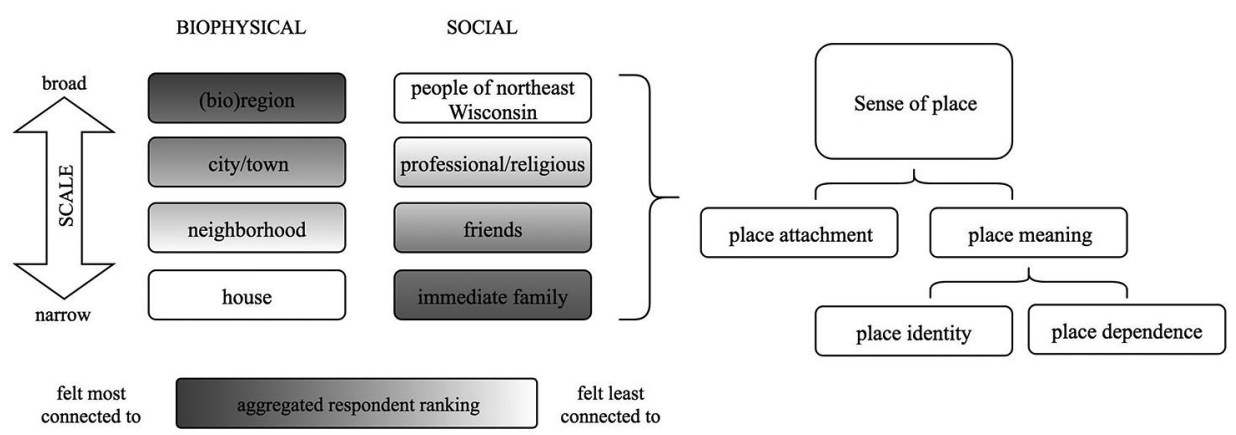

Figure 3. Conceptual model demonstrating the observed patterns between scale and intensity of biophysical versus social dimensions of place attachment 


\section{Table 3. Perceived bioregional boundaries and characteristics}

\begin{tabular}{|c|c|c|c|}
\hline $\begin{array}{l}\text { Perceived bioregional } \\
\text { boundary distinctions } \\
\text { (code frequency) }\end{array}$ & $\begin{array}{l}\text { Bioregional } \\
\text { characteristics: } \\
\text { Fox River Valley }\end{array}$ & Northwoods & Door Peninsula \\
\hline $\begin{array}{l}\text { landscape-e.g., } \\
\text { land cover, land use, } \\
\text { landforms (51) }\end{array}$ & $\begin{array}{l}\text { farmland } \\
\text { "big" agriculture (dairies) } \\
\text { industry/shipping } \\
\text { water (rivers and bay of GB) }\end{array}$ & $\begin{array}{l}\text { hardwood forest } \\
\text { logging/forest } \\
\text { products } \\
\text { water (small lakes) }\end{array}$ & $\begin{array}{l}\text { "small” agriculture } \\
\text { (orchards) } \\
\text { water (Lake Michigan) } \\
\text { geology (Niagara } \\
\text { escarpment) }\end{array}$ \\
\hline population density (21) & $\begin{array}{l}\text { high/urban } \\
\text { intensifying/growing }\end{array}$ & low/dispersed & $\begin{array}{l}\text { low/dispersed } \\
\text { rural }\end{array}$ \\
\hline human culture (15) & $\begin{array}{l}\text { urban amenities (food, } \\
\text { retail) } \\
\text { recreation (boating, hiking, } \\
\text { fishing) } \\
\text { home/community }\end{array}$ & $\begin{array}{l}\text { isolated, small-town } \\
\text { family-/vacation- } \\
\text { oriented } \\
\text { recreation (hunting, } \\
\text { fishing) }\end{array}$ & $\begin{array}{l}\text { touristy } \\
\text { recreation (camping, } \\
\text { agritourism) }\end{array}$ \\
\hline $\begin{array}{l}\text { incommensurable } \\
\text { "feel" (12) }\end{array}$ & changing/growing & $\begin{array}{l}\text { quiet/solitude } \\
\text { "get away from it all" }\end{array}$ & $\begin{array}{l}\text { vacation } \\
\text { aesthetically appealing }\end{array}$ \\
\hline relative pristineness (6) & $\begin{array}{l}\text { dirty/polluted } \\
\text { cleaning up (ecologically) }\end{array}$ & $\begin{array}{l}\text { more "natural" } \\
\text { clean }\end{array}$ & $\begin{array}{l}\text { pristine (water) } \\
\text { scenic, well-managed } \\
\text { (land) }\end{array}$ \\
\hline
\end{tabular}

Note. Column one contains codes that represent the various ways in which respondents perceive differences between northeastern Wisconsin's three bioregions, specifically in reference to the questions How is/are the (DP/Northwoods) different from the FRV? and Where does/do the (DP/Northwoods) start, relative to the FRV? Columns two through four represent the most salient characteristics that people associated with each bioregion, aggregated from responses to all interview questions.

For her and others, the bioregion and its nested watersheds offer a recognizable and graspable frame for conceptualizing water challenges and their associated solutions. Another longtime resident, who had spent more than 20 years doing water quality monitoring, restoration, and advocacy on behalf of Baird Creek and its associated sub-watershed, talked about his vision for change:

In the long term, I think most of us understand the bay [of GB] and the problems that the bay has, and that's really what we're looking for. We want clean water all the way out, and not just Baird Creek, and that's what we're going to do, I can see it coming. It's going to be a lot of money, but I think stream by stream eventually you pick up a lot of that contamination.

For him, care for place is not limited to just Baird Creek or its surrounding uplands, but is extended to the rest of the surrounding FRV and its qualitatively similar landscape patterns. Increasingly, he and other respondents view this broader-scale vision - one that capitalizes on the best and most iconic parts of this mixed-amenity place-being shared by other actors in the FRV. Many respondents described using watershed-wide restoration projects like Baird Creek as a hub for both building positive place bonds in the broader community, and modeling what improved ecologic conditions (especially water quality) could look like in the FRV's other major and minor tributaries. 


\section{Discussion}

This article set out to investigate the scale and biophysical dimensions of people's sense of place in mixed-amenity bioregions. The biophysical environment was indeed a core dimension of most people's sense of place, and seems to operate as an important influence on the socially constructed meanings and experiences that comprise participants' overall sense of place. Like Stedman's (2003) study of lake homeowners in the Northwoods, we certainly found evidence for a constructed, meaningmediated linkage between any given biophysical feature and people's expressed attachment to it; many participants, for example, were not attached to Baird Creek's individual trees or pools of water, but rather expressed attachment to the meaning of solitude that they associated with Baird Creek. Despite the likelihood that this meaning-mediated pathway explains some biophysical attachments, our findings suggest that places' sensory characteristics and place-enabled experiences may be equally important factors. Participants in our study most frequently expressed an affinity for the sound and sight of moving water, often manifested in stream currents and lake waves. However, other sensory experiences_-particular smells, or feelings of dampness or warmth-emerged as well, supporting Cross's (2015) finding that sensory experiences comprise one of seven sense-of-place development processes. Similarly, we found evidence for places' biophysical characteristics enabling certain kinds of personally significant experiences, which over time contribute to a sense of place. For example, the FRV's climate and the bay of GB's size both enable certain forms of recreation that are simply not possible in other places. Likewise, the proximate location of and rich biodiversity in the Baird Creek sub-watershed enable a panoply of educational, recreational, and community-building opportunities. While some participants readily acknowledged that they could, for example, find hunting or fishing opportunities in other parts of the country, they nevertheless were unequivocal in expressing the importance of these place-enabled experiences in contributing to their overall sense of place in northeast Wisconsin.

When studying how biophysical characteristics influence sense of place development, it is tempting to draw causal relationships that are either (1) overly essentialized and too deterministic (e.g., biophysical places are imbued with sensory and experiential qualities that will be perceived and understood in the same way by all people) or (2) are too abstracted, relativistic, or socially constructed (e.g., people are only attached to the meaning of solitude or wilderness, which could be associated with any number of places, and can only be understood from a single individual's perspective). Instead, our findings support Williams's (2014) proposed spectrum of pathways between a physical place and sense of place, in which place meanings and experiences range are variously salient, shared, and constructed. In other words, any given place has certain salient, physical properties that may be more universally perceivable, compared to more abstracted place meanings, which may be multiple 
and highly variable, depending on individuals' or groups cultural and social constructions. To reframe our results in this context, we return to a place-memory shared by one of our participants, who talked about the regular act of visiting Lake Michigan's Cave Point in winter with his wife to catch a glimpse of rare sea ducks. He talked about the sensory experiences of building a fire, sharing a bottle of wine, and listening to the lake's waves. According to the meaning-mediated model, this place-based memory contributes to the participant's sense of place only insofar as it allows him to construct abstracted mental meanings that are associated with Cave Point (e.g., solitude, familial intimacy) and to which he becomes attached over time. Alternatively, the synoptic spectrum model allows for both the meaning-mediated link between place and a person's sense of place, as well as sensory, ritualistic, and experientially significant encounters with place. It is crucial to point out, however, that we do not view these landscape and biophysically oriented dimensions of sense of place as operationally or conceptually distinct from a sense of place's social dimensions; rather, we argue that the former influences the latter in potentially significant ways that deserve further research. For example, how does the relative salience of these sense of place linkages/pathways vary among different kinds of places (e.g., mixed-amenity, high-amenity, recreational, utilitarian)? How exclusive or synergistic are these pathways vis-à-vis contributing to a person's sense of place? Further, how does overall sense of place vary across different landscapes?

Finally, in keeping with calls from Ardoin (2014) and others, we considered how sense of place varied across spatial scales. Overall, respondents' social sense of place was strongest at narrower scales, namely the house and family, and decreased across spatially broader valances. These are mostly consistent with the findings of Hidalgo and Hernandez (2001). Contrastingly, participants' biophysical sense of place was strongest at the bioregional scale, followed by the bay of GB and incrementally smaller landscape units. Respondents expressed a strong affinity for the climate, terrestrial, and aquatic landscapes, of northeastern Wisconsin's bioregions, as well as their associated meanings, sensory qualities, and recreational opportunities. Participants talked about bioregional characteristics, including both ecological and sociocultural distinctions, with fluency and ease and in some cases implicitly used bioregions as a framework for conceptualizing and motivating their conservation activities and visions. These findings regarding broad-scale sense of place and broadscale action are consistent with those of Ardoin (2014), yet inconsistent with Forsyth et al. (2015), who observed a statistical association between scale, attachment, and behavior only at the neighborhood/community level, not at broader spatial valences. This inconsistency may be explained in part by marked differences in sampling and measurement approaches, and the fact that Forsyth and colleagues used participants' county of residence as their largest spatial unit. Based on our findings, people's overall sense of place (and associated behaviors) may very well operate quite differently at political boundaries (e.g., counties) than they do at more bioregionally or ecoregionally oriented boundaries. 


\section{Conclusions}

Our findings fulfilled our objectives of understanding:

1. how scale may operate and affect the biophysical and social dimensions of place attachment

2. whether and how bioregional patterns are perceived and related to the biophysical dimension of sense of place.

These results add to the scant literature on scales of sense of place, which has to date found inconsistent correlations between scale and the intensity of people's sense of place. To our knowledge, we are the first to consider sense of place through the scalar and heuristic lens of the bioregion. We found this spatial frame to be a useful starting point for triangulating participants' multiple place attachments, identities, and dependencies; bioregions' explicit inclusion of both human and landscape characteristics, we argue, makes them particularly amenable to studying the multiple dimensions of sense of place. Further, the bioregional identities, attachments, and preferences that our participants expressed did not align with the territorial provincialism criticized by Massey (1994) and others, who have argued in favor of cosmopolitan, global senses of place. Our respondents' regional and bioregional ties to northeastern Wisconsin were strongly associated with a perceived regional distinctiveness and uniqueness and did not preclude their recognition of the need for even broader-scale (e.g., state, national, global) cooperation and exchanges ideas. However, rather than resulting in an exclusive sense of superiority, these regional and bioregional place bonds acted as magnets that motivated longterm commitments to place among otherwise-mobile people. These regional and bioregional frames, moreover, served as graspable touchstones for conceptualizing environmental problems and their related solutions, and for supporting their longterm commitments and visions for ecosystem care and restoration.

Given the limitations of our relatively small and purposive sample, future quantitative and qualitative research is necessary for more robustly understanding how broadscale, bioregional senses of place vary across both adjacent and non-adjacent bioregions, and how these affect landscape-related behaviors. Subsequent research in our study site, for example, could investigate whether or not it is necessary for farmers farther up in the FRV's watershed to develop a bioregional sense of place to feel motivated to install riparian buffers or modify their manure-spreading schedule. In addition to addressing behavioral causality, future investigations of sense and scale of place must account for two considerations. First, if hypothesizing a relationship between scale of place and environmental behaviors, measurement instruments must explicitly account for differences between biophysical and social dimensions of sense of place, and how their relative intensity varies across scales (c.f. Scannell \& Gifford, 2010a). Second, measurement approaches must more precisely align participants' 
scale of place and the scale of the conservation or pro-environmental behaviors in question-that is, pro-environmental behaviors should not all be viewed as equal when it comes to assessing their associations with people's scale of place.

\section{References}

Ardoin, N. M. (2014). Exploring sense of place and environmental behavior at an ecoregional scale in three sites. Human Ecology, 42(3), 425-441. doi.org/10.1007/ s10745-014-9652-x

Ardoin, N. M., Schuh, J. S., \& Gould, R. K. (2012). Exploring the dimensions of place: A confirmatory factor analysis of data from three ecoregional sites. Environmental Education Research, 18(5), 583-607. doi.org/10.1080/13504622.2011.640930

Banting, P. (2012). The bioregional imagination: Literature, ecology, and place. IsleInterdisciplinary Studies in Literature and Environment, 19(4), 788-789. doi.org/10.1093/ isle/iss092

Beckley, T. M. (2003). The relative importance of sociocultural and ecological factors in attachment to place. United States Department of Agriculture Forest Service General Technical Report PNW, 105-126.

Bell, M. M., \& Ashwood, L. L. (2015). An invitation to environmental sociology: London, UK: Sage Publications.

Berthold-Bond, D. (2000). The ethics of "place": Reflections on bioregionalism. Environmental Ethics, 22(1), 5-24. doi.org/10.5840/enviroethics200022146

Brazner, J. C. (1997). Regional, habitat, and human development influences on coastal wetland and beach fish assemblages in Green Bay, Lake Michigan. Journal of Great Lakes Research, 23(1), 36-51. doi.org/10.1016/S0380-1330(97)70883-9

Carolan, M. S. (2005). Realism without reductionism: Toward an ecologically embedded sociology. Human Ecology Review, 12(1), 1-20.

Carrus, G., Bonaiuto, M., \& Bonnes, M. (2005). Environmental concern, regional identity, and support for protected areas in Italy. Environment and Behavior, 37(2), 237-257. doi.org/10.1177/0013916504269644

Cresswell, T. (2004). Place: A short introduction. Coventry, UK: Blackwell.

Cross, J. E. (2015). Processes of place attachment: An interactional framework. Symbolic Interaction, 38(4), 493-520. doi.org/10.1002/symb.198

Dunlap, R. E., \& Catton, W. R. (1979). Environmental sociology. Annual Review of Sociology, 243-273. doi.org/10.1146/annurev.so.05.080179.001331 
Forsyth, D. R., van Vugt, M., Schlein, G., \& Story, P. A. (2015). Identity and sustainability: Localized sense of community increases environmental engagement. Analyses of Social Issues and Public Policy, 15(1), 233-252. doi.org/10.1111/asap.12076

Gifford, R. (2014). Environmental psychology matters. Annual Review of Psychology, 65, 541-579. doi.org/10.1146/annurev-psych-010213-115048

Gosling, E., \& Williams, K. J. H. (2010). Connectedness to nature, place attachment and conservation behaviour: Testing connectedness theory among farmers. Journal of Environmental Psychology, 30(3), 298-304. doi.org/10.1016/j.jenvp.2010.01.005

Hidalgo, M. C., \& Hernandez, B. (2001). Place attachment: Conceptual and empirical questions. Journal of Environmental Psychology, 21(3), 273-281. doi.org/10.1006/ jevp.2001.0221

Jorgensen, B. S., \& Stedman, R. C. (2001). Sense of place as an attitude: Lakeshore owners attitudes toward their properties. Journal of Environmental Psychology, 21(3), 233-248. doi.org/10.1006/jevp.2001.0226

Knez, I. (2005). Attachment and identity as related to a place and its perceived climate. Journal of Environmental Psychology, 25(2), 207-218. doi.org/10.1016/j.jenvp.2005.03.003

Kudryavtsev, A., Stedman, R. C., \& Krasny, M. E. (2012). Sense of place in environmental education. Environmental Education Research, 18(2), 229-250. doi.org/10.1080/13504 622.2011 .609615

Kyle, G., Graefe, A., Manning, R., \& Bacon, J. (2004). Effects of place attachment on users' perceptions of social and environmental conditions in a natural setting. Journal of Environmental Psychology, 24(2), 213-225. doi.org/10.1016/j.jenvp.2003.12.006

Least Heat-Moon, W. (1991). PrairyErth (a deep map): An epic history of the tallgrass prairie country. Boston: Houghton Mifflin Company.

Lewicka, M. (2010). What makes neighborhood different from home and city? Effects of place scale on place attachment. Journal of Environmental Psychology, 30(1), 35-51. doi.org/10.1016/j.jenvp.2009.05.004

Lewicka, M. (2011). Place attachment: How far have we come in the last 40 years? Journal of Environmental Psychology, 31(3), 207-230. doi.org/10.1016/j.jenvp.2010.10.001

Lukacs, H. A., \& Ardoin, N. M. (2014). The relationship of place re-making and watershed group participation in Appalachia. Society \& Natural Resources, 27(1), 55-69. doi.org/ 10.1080/08941920.2013.840876

Manzo, L. C., \& Perkins, D. D. (2006). Finding common ground: The importance of place attachment to community participation and planning. Journal of Planning Literature, 20(4), 335-350. doi.org/10.1177/0885412205286160

Massey, D. (1994). Space, place, and gender. Cambridge, UK: Polity Press. 
Miles, M. B., \& Huberman, A. M. (1994). Qualitative data analysis: An expanded sourcebook. London UK: Sage Publications.

Mullendore, N. D., Ulrich-Schad, J. D., \& Prokopy, L. S. (2015). US farmers' sense of place and its relation to conservation behavior. Landscape and Urban Planning, 140, 67-75. doi.org/10.1016/j.landurbplan.2015.04.005

Olsen, J. (2000). The perils of rootedness: On bioregionalism and right wing ecology in Germany. Landscape Journal, 19(1-2), 73-83. doi.org/10.3368/lj.19.1-2.73

Painter, J. (2008). Cartographic anxiety and the search for regionality. Environment and Planning A, 40(2), 342-361. doi.org/10.1068/a38255

Patterson, M. E., \& Williams, D. R. (2002). Collecting and analyzing qualitative data: Hermeneutic principles, methods and case examples. Advances in Tourism Applications Series, 9. Champaign, IL: Sagamore Publishing, Inc.

Patterson, M. E., \& Williams, D. R. (2005). Maintaining research traditions on place: Diversity of thought and scientific progress. Journal of Environmental Psychology, 25(4), 361-380. doi.org/10.1016/j.jenvp.2005.10.001

Proshansky, H. M. (1978). City and self-identity. Environment and Behavior, 10(2), 147-169 doi.org/10.1177/0013916578102002

Relph, E. (1976). Place and placelessness (Vol. 67). London: Pion.

Relph, E. (1981). Rational landscapes and humanistic geography. New York: Barnes \& Noble.

Rutherford, M. C., Mucina, L., \& Powrie, L. W. (2006). The vegetation of South Africa, Lesotho and Swaziland. Strelitzia 19, 30-51. South African National Biodiversity Institute, Pretoria.

Sale, K. (1985). Bioregionalism-a sense of place. Nation, 241(11), 336-339.

Scannell, L., \& Gifford, R. (2010a). Defining place attachment: A tripartite organizing framework. Journal of Environmental Psychology, 30(1), 1-10. doi.org/10.1016/j. jenvp.2009.09.006

Scannell, L., \& Gifford, R. (2010b). The relations between natural and civic place attachment and pro-environmental behavior. Journal of Environmental Psychology, 30(3), 289-297. doi.org/10.1016/j.jenvp.2010.01.010

Schama, S. (1995). Landscape and Memory. New York, NY: Alfred and Knopf.

Selman, P. (2006). Planning at the landscape scale: Abington, UK: Routledge.

Stedman, R. C. (2003). Is it really just a social construction? The contribution of the physical environment to sense of place. Society \& Natural Resources, 16(8), 671-685. doi.org/10.1080/08941920390217627 
Stokols, D., \& Shumaker, S. A. (1981). People in places: A transactional view of settings. In J. Harvey (Ed.), Cognition, Social Behavior and Environment. Hillsdale, NJ: Erlbaum.

Thayer, R. L. (2003). Lifeplace: Bioregional thought and practice. Berkley, CA: University of California.

Timmermans, S., \& Tavory, I. (2012). Theory construction in qualitative research: From grounded theory to abductive analysis. Sociological Theory, 30(3), 167-186. doi.org/ $10.1177 / 0735275112457914$

Trentelman, C. K. (2009). Place attachment and community attachment: A primer grounded in the lived experience of a community sociologist. Society \& Natural Resources, 22(3), 191-210. doi.org/10.1080/08941920802191712

Tuan, Y.-F. (1977). Space \& place: The perspective of experience. Minneapolis: University of Minnesota.

US Environmental Protection Agency. (2013). Level III ecoregions of the continental United States. Corvallis, Oregon: EPA, National Health and Environmental Effects Research Laboratory. Retrieved from: www.epa.gov/eco-research/level-iii-and-ivecoregions-continental-united-states

Vander Zanden, M. J., \& Olden, J. D. (2008). A management framework for preventing the secondary spread of aquatic invasive species. Canadian Journal of Fisheries and Aquatic Sciences, 65(7), 1512-1522. doi.org/10.1139/F08-099

Vaske, J. J., \& Kobrin, K. C. (2001). Place attachment and environmentally responsible behavior. The Journal of Environmental Education, 32(4), 16-21. doi. org/10.1080/00958960109598658

Williams, D. R. (2014). Making sense of 'place': Reflections on pluralism and positionality in place research. Landscape and Urban Planning, 131, 74-82. doi.org/10.1016/ j.landurbplan.2014.08.002 
This text is taken from Human Ecology Review, Volume 24, Number 1, 2018, published 2018 by ANU Press, The Australian National University, Canberra, Australia.

doi.org/10.22459/HER.24.01.2018.04 